\title{
CIUDADANOS NEGROS \\ EN EL RÍO DE LA PLATA. \\ REPENSAR LA INCLUSIÓN POLÍTICA \\ DE LOS EMANCIPADOS ENTRE \\ LA REVOLUCIÓN Y LA CONSTITUCIÓN ${ }^{1}$
}

\author{
BLACK CITIZENS IN THE RÍO DE LA PLATA: \\ RETHINKING THE POLITICAL INCLUSION \\ OF THE EMANCIPATED BETWEEN \\ THE REVOLUTION AND THE CONSTITUTION \\ MAGDALENA CANDIOTI •
}

Magdalena Candioti es Investigadora Asistente del Consejo Nacional de Investigaciones Científicas y Técnicas (CONICET) con sede en el Instituto Ravig-

\section{Resumen}

El presente artículo busca periodizar y contextualizar la relación entre la (re)definición de la ciudadanía y los modos de construcción de diferencias raciales en el Río de la Plata entre los años 1810 y 1853 a fin de discutir específicamente la supuesta insignificancia de las distinciones fundadas en la afrodescendencia, el pasado esclavo y el color a la hora de definir la inclusión política de los tras la revolución y hasta la organización constitucional. nani y Profesora Adjunta Regular en la Universidad Nacional del Litoral.

E-mail: mcandioti@yahoo.com

\section{Abstract}

This article seeks to periodize and contextualize the historical relationship between the (re)definition of citizenship and the construction of racial differences in the River Plate between 1810 and 1853 and, in particular, it specifically discuss the alleged insignificance of distinctions based on African descent, slave past and color in the definition of the political in the River Plate after the revolution and until the constitutional organization.

\footnotetext{
${ }^{1}$ El trabajo se inserta en el PICT 2014-2097 «Esclavitud y abolición en Buenos Aires y Santa Fe: perspectivas comparadas sobre el proceso de erosión de la institución esclavista en las primeras décadas republicanas (1810-1853)», Agencia Nacional de Promoción Científica y Tecnológica, Argentina. Fue posible también gracias a la beca de la Fundación Slicher Van Bath de Jong para la promoción del estudio y la investigación de la historia de América Latina. Agradezco especialmente los comentarios de los evaluadores del artículo.
} 